\title{
INFLUENCE OF SOIL TYPE DIFFERENCES ON THE DISTRIBUTION OF DTPA EXTRACTABLE HEAVY METALS IN SOILS IRRIGATED WITH INDUSTRIAL EFFLUENTS
}

\author{
Fisseha Itanna ${ }^{1}$ Darwin Anderson ${ }^{2}$ and Karl Stahr ${ }^{3}$ \\ ${ }^{1}$ Department of Biology, Faculty of Science, Addis Ababa University, PO. Box 1176, \\ Addis Ababa, Ethiopia, e-mail: fissehai@bio.aau.edu.et \\ ${ }^{2}$ Department of Soil Science, University of Saskatchewan, S7N 5A8 Saskatoon, Canada \\ ${ }^{3}$ Institute of Soil Science and Land Evaluation, University of Hohenheim, \\ Emil Wolff Str. 27, D-70593 Stuttgart, Germany
}

\begin{abstract}
This study determined the effects of the application of industrial liquid waste from a textile factory on the distribution of DTPA extractable metals in a Pelli-Eutric Vertisol and an Eutric Fluvisol at Akaki in Ethiopia, classified according to the FAO-UNESCO Soil Classification System. The Fluvisol is slightly basic on the surface and has sandy clay to clay loam texture, while the Vertisol is strongly basic on the surface, and has clayey texture throughout the profile. Application of the industrial liquid waste modified and increased levels of DTPA metals in the treated Akaki soils compared to natural levels in the background soils. The Fluvisol has more DTPA extractable Fe, Mn, and $\mathrm{Zn}$ than the Vertisol. Surface $\mathrm{Cu}, \mathrm{Cd}$ and $\mathrm{Ni}$ contents are higher in the Vertisol opposed to the Fluvisol. However, there is more enrichment of these metals within depth, in the Fluvisol. Pb concentrations in the Fluvisol are about twice as much as the Vertisol throughout the profile. Soil solution $\mathrm{pH}$ seems to have the greatest influence for most metals. Surface $\mathrm{Cu}$ and $\mathrm{Ni}$ of the treated Vertisol are more influenced by organic matter, while on the whole CEC has negative influence on metal availability because of competing ions. These metals generally decrease consistently with depth in the Vertisol, while in the Fluvisol the profile distribution is irregular. Leaching due to coarser textural composition and floodplain soil impacted by the contaminated river sediments are responsible for metal redistribution in the Fluvisol than in the Vertisol. There is thus greater risk of metal uptake by vegetables on the Fluvisol than the Vertisol.
\end{abstract}

Key words/phrases: Background soils, contaminated soils, Fluvisol, industrial waste, Vertisol

\section{INTRODUCTION}

Disposal of municipal sewage sludge and industrial wastewater on agricultural soils is becoming a routine practice (Valdares et al., 1983; Bidwell and Dowdy, 1987). Agricultural soils may also receive other anthropogenic additions from practices such as the application of fertilizers and pesticides; additives in animal feeds and atmospheric deposition (McBride, 1995). The concern for the disposal of such wastes is related to heavy metal build up, which can induce metal toxicity and can be risky for human health (Ma and Rao, 1997). Entrance into groundwater is the other risk anticipated from the movement of metals through the soil column.

The potential benefits of such additions have also been discussed by some researchers (Sheaffer et al., 1979), who claim that the high levels of N, P, and micronutrients found in sewage sludge make it an excellent fertilizer. They also explain the advantages of soil organic matter in improving soil structure as a result of sewage sludge additions. Some claim that such a practice on agricultural soils is favored as a means of disposal and beneficial reuse (Yingming and Corey, 1993).

Vegetable growers at Akaki in Ethiopia, utilize the industrial liquid waste to irrigate their crops, especially during the dry period. Consequently, their farmlands are exposed to heavy metal buildup from the application of the industrial effluents. Experience in the past has shown that discharges from different industrial sources have led to localized soil pollution through accumulation of some potentially toxic elements (Venditti et al., 2000).

The major soil types on one of the big farms at Akaki which are irrigated with the industrial liquid waste are, a Vertisol on the upper ground and a Fluvisol on the lower terrace and adjacent to the Akaki River. In the major industrial zone in Ethiopia, which extends to a distance of about 70 kms between Addis Ababa and Modjo, Fluvisols and Vertisols are the dominant soil types that are 
irrigated under similar conditions for vegetable production.

Earlier study on the total heavy metal contents of Akaki soils reveals that total $\mathrm{Ni}$ and total $\mathrm{Cr}$ contents are in the toxic range (Fisseha Itanna, 1998a). It is however, the bioavailable forms rather than total contents that are important in plant uptake. Consequently, the DTPA extractant has been selected to determine the extractable forms of the micronutrients and some of the other heavy metals. Adriano (1986) explains that the DTPA extraction is used routinely as general soil test for micronutrients and metals. Korcak and Fanning (1978) found DTPA to be superior over a wider range of soil conditions compared to other methods.

The bioavailable form of a trace metal is that fraction which becomes plant available. In recent years, sequential extraction techniques have been employed to fractionate heavy metals in soils into a variety of operationally defined geochemical pools (Sloan et al., 1997). Some of the major metal fractions include: soluble and exchangeable, specifically adsorbed and weakly bound, easily reducible $\mathrm{Fe} / \mathrm{Mn}$ oxides, organically complexed, residual organic and residual inorganic. Metals in water soluble and exchangeable fractions would be readily bioavailable, whereas the metals in the residual fraction are tightly bound and would not be expected to be released under natural conditions (Ma and Rao, 1997).

Concentrations and distribution of heavy metals in different soil types are expected not to be the same, since there will be differences in the soil chemical, physical, biological and mineralogical properties. Metal activity in the soil solution is generally influenced by metal equilibria among clay minerals, organic matter, hydrous oxides of $\mathrm{Fe}, \mathrm{Mn}$, and $\mathrm{Al}$, and soluble chelators, with the soil $\mathrm{pH}$ strongly affecting these equilibria (Lindsay, 1979).

The concentrations of BOD (biological oxygen demand), COD (chemical oxygen demand), TDS (total dissolved salts), and TSS (total soluble salts) in the Akaki Textile Factory effluent from the preparation room are 2460,6720, 9300, and 4230 $\mathrm{mg} / \mathrm{l}$, respectively. On the other hand, the concentrations of the BOD, COD, and TDS in the effluent from the dyeing room are, 154, 615, and $4615 \mathrm{mg} / \mathrm{l}$, respectively.

Generally, heavy metals are considered immobile and hence their concentrations are higher on the surface and decline with soil depth. However, with factors like soil textural differences, distribution of some metals like Mn and Ni have been found to show irregularities (Adriano, 1986). Stirring of soils with neutral $(6,6-7,6 \mathrm{pH})$ and acidified water $(\mathrm{pH} 4.5)$, have resulted in leaching of some heavy metals (Venditti et al., 2000).

The major objective of this study is to examine and compare which of the two contaminated soils; namely, Fluvisol and Vertisol, could influence more the availability and distribution of some heavy metals in soils. The outcome will thus assist to advise farmers on which soil type there is greater risk of contamination. Moreover, since these two soils are the predominant soil types on which vegetables are produced using river water in the major industrial section of the country, the results will have wider application. The study also compares the metal status of the contaminated soils with similar background soils in the vicinity, in order to assess the extent of metal pollution.

\section{MATERIALS AND METHODS}

Akaki is a small industrial town in Ethiopia, about $20 \mathrm{kms}$ southeast of Addis Ababa. The Akaki River flows through Addis Ababa, passes through Akaki, and continues southwards to join the Awash River. Because of the river and the good market in Addis Ababa, vegetables are grown here throughout the year. One of the vegetable farms irrigated with industrial liquid waste from the Akaki Textile Factory has been selected for this study.

The farm under investigation belongs to the Fanta Farmers' Cooperative. The total area of this farm is about $15000 \mathrm{~m}^{2}$. Land is prepared either through oxen ploughing or hand digging with hoes. Furrows and ridges are made by hand tools, for water management and planting purposes, respectively. Except for potatoes, seeds of vegetables such as cabbage, carrot, tomatoes, Swiss chard, lettuce are sown on well-prepared seedbeds. The seedlings are then transplanted on major fields. Potato is grown from tubers. The liquid waste from the Akaki Textile Factory, that is used as irrigation water enters the farm through bigger waterways and is later distributed to individual plots through the smaller furrows. The distance between the effluent discharge and its entrance into the farm is about $200 \mathrm{~m}$. The irrigation water is regularly administered to the farms during the dry season. Occasionally, when the irrigation water is in short supply, farmers pump water from the nearby Akaki River into the farm.

The FAO/UNESCO classification with revised legend was used to classify the soils based on their 
diagnostic horizons and properties (FAO, 1988). Accordingly, two soil types were identified in the study area. The soil representing the sloping and footslope positions is classified as Vertisol at the first unit level, because of its high clay content throughout the profile (i.e., $>60 \%$ ) and other vertic properties, such as slickensides and cracks. Since the Vertisol of the study site does not have the gypsic and calcic horizons of Gypsic and Calcic Vertisols, and that it has a base saturation exceeding that of a Dystric Vertisol; it is classified as Eutric Vertisol. Considering the colour of the soil as a subunit, which gives additional characteristic to the first and second level units, the soil can eventually be classified as Pelli-Eutric Vertisol (FAO, 1988).

The soil at toeslope position is classified as a Fluvisol at the first unit level, because it shows fluvic properties; and is further classified as an Eutric Fluvisol because it lacks the salt, $\mathrm{CaCO}_{3}$, and base saturation of the other Fluvisols (FAO, 1988).

Representative sites for each of the soil types were later identified and selected for soil sampling. The Vertisol pit was dug at the footslope position (lowest position for the Vertisols) in the farm about $50 \mathrm{~m}$ from the Fluvisol, which lied at a toeslope position. The slope of the landscape (in which both soils fall in) is between $0-2 \%$.

Surface soil $(0-20 \mathrm{~cm})$ adjacent to the respective profile pits, and profile samples from the different horizons, were collected from both soil types. In the case of surface samples, twenty auger subsamples were taken from the fields adjacent to each soil type and later bulked, thus forming two separate bulk samples. Sufficient amount was saved from the bulk samples for different chemical and physical analyses. In the case of profile samples, they were taken from each horizon of the two soil types. Again, several sub-samples were put together from each horizon to form a bulk sample. The soil samples were then air-dried and crushed to pass a 2-mm mesh sieve.

Metal adsorption in soils is greatly influenced by soil $\mathrm{pH}$, cation exchange capacity (CEC), organic carbon content, clay content, and hydrous Fe and Mn oxide contents (Basta and Tabatabai, 1992). Accordingly, except the hydrous oxides of Fe and $\mathrm{Mn}$ all the other parameters were determined.

The $\mathrm{pH}$ of the soils was determined potentiometrically from a 1:2 (soil:water) or 1:2 (soil:0.01M $\mathrm{CaCl}_{2}$ ) solutions occasionally stirred with glass rods, with a PHM standard $\mathrm{pH}$ meter. Texture was determined by the pipette method and carbonate contents were calculated from readings of a 1:1 (soil:water) extraction, using the METROHM 655 Dosimat with an E526 titrator. Organic carbon was measured using a LECO CR-12 carbon analyzer. Total carbon was determined with a CNS analyzer.

The DTPA extracting solution applied in soil by Lindsay and Norvell (1978) was used to extract plant available metals in the soil samples. Twenty $\mathrm{mL}$ of the DTPA solution was added into each of 10 $\mathrm{g}$ of air-dried soil samples in a 125-mL flask and shaken for exactly 2 hours (Risser and Baker, 1990). The suspension was filtered with Whatman No. 42 filter paper. The filtrate was analyzed for $\mathrm{Cd}, \mathrm{Cu}$, $\mathrm{Fe}, \mathrm{Mn}, \mathrm{Ni}, \mathrm{Pb}$ and $\mathrm{Zn}$ with Perkin Elmer AAS 3100, using acetylene air flame. For the total analyses, $0.5 \mathrm{~g}$ of finely ground soil samples were placed each in a Teflon digestion vessel and digested with $8 \mathrm{ml} \mathrm{HNO}_{3}$ and $4 \mathrm{ml} \mathrm{HF}$ in a microwave digestion system. Total soil metals were then determined using a PE Elan 5000 ICP-MS.

All parameters mentioned above are determined from duplicate samples and the final value is computed from an average of the duplicates. Comparisons of metals within profiles have also been made based on the weighted averages of the metals of the two soil profiles.

\section{RESULTS AND DISCUSSION}

\section{Differences in soil types}

The $\mathrm{pH}$ of the Vertisol declines from strongly basic in the upper horizons to moderately basic $\mathrm{pH}$ in the lower horizons; whereas, that of the Fluvisol increases from a slightly basic at the uppermost horizon to moderately basic soil reaction in the underlying horizons (Table 1).

Horizons of both soils do not show any effervescence to dilute $\mathrm{HCl}$, and there is no $\mathrm{CO}_{3}$ in these soils. The total $\mathrm{C}$ content of these soils is generally low decreasing from surface to underlying horizons. The organic $\mathrm{C}$ content shows similar trend. Surface concentrations of carbon of the Vertisol are higher than surface $C$ in the Fluvisol. The Vertisol has clayey texture throughout the horizons; whereas, the Fluvisol has a sandy clay surface texture, and is variable with depth. The clay fractions in the Vertisol are about twice as much as that of the Fluvisol. The CEC (cation exchange capacity) of the Vertisol is also higher than the Fluvisol because of the high clay fraction in the Vertisol. Consequently, there is more adsorption of basic cations like $\mathrm{Ca}$, and $\mathrm{Mg}$ on this soil than the Fluvisol. 
Table 1. Some chemical and physical properties of the Akaki treated soils.

\begin{tabular}{|c|c|c|c|c|c|c|c|c|}
\hline Depth & Soil & $\mathrm{pH} / \mathrm{H}_{2} \mathrm{O}$ & $\mathrm{pH} / 0.1 \mathrm{M}$ & OC & CEC & Sand & Silt & Clay \\
\hline$(\mathrm{cm})$ & Horizon & $1: 2$ & $\mathrm{CaCl}_{2} / 1: 2$ & $\%$ & $\mathrm{Cmol} \mathrm{kg}^{-1}$ & & $\%$ & \\
\hline \multicolumn{9}{|c|}{ a. Vertisol } \\
\hline $0-30$ & Ap & 8.8 & 7.9 & 2.1 & 59.0 & 4.7 & 23.5 & 71.8 \\
\hline $30-85$ & $\mathrm{~B}$ & 8.7 & 8.1 & 1.3 & 63.8 & 2.1 & 20.0 & 77.9 \\
\hline $85-115$ & BC & 8.3 & 7.7 & 1.0 & 57.9 & 3.9 & 29.1 & 67.0 \\
\hline $115+$ & $\mathrm{C}$ & 8.1 & 7.5 & 0.7 & 50.0 & 5.4 & 32.6 & 62.0 \\
\hline \multicolumn{9}{|c|}{ b. Fluvisol } \\
\hline $0-25$ & Ap & 7.9 & 7.5 & 1.2 & 37.0 & 46.4 & 18.1 & 35.5 \\
\hline $25-80$ & $\mathrm{~B}$ & 8.2 & 7.4 & 1.2 & 37.8 & 37.6 & 26.2 & 36.2 \\
\hline $80-100$ & AIIb & 8.1 & 7.3 & 0.6 & 37.3 & 42.6 & 21.6 & 35.8 \\
\hline $100-137$ & BIIb & 8.4 & 7.2 & 0.7 & 40.7 & 36.1 & 21.5 & 42.4 \\
\hline $137+$ & $\mathrm{C}$ & 8.4 & 7.2 & 0.7 & 38.6 & 40.9 & 20.5 & 38.6 \\
\hline
\end{tabular}

\section{Metal concentrations in wastewater applied on treated soils}

Both soil types are irrigated with industrial wastewater especially during the dry months, and this kind of wastewater application has been practiced on the farms for over three decades. The amount of wastewater discharged from textile factories ranks the highest when comparing quantity of wastewater discharged from different industrial sources in Ethiopia. For instance, in Addis Ababa alone about 1,992,597 $\mathrm{m}^{3} / \mathrm{yr}$ of wastewater is discharged from textile factories.

According to recent analytic results of water sample from the Akaki industrial effluent, concentrations $\left(\mu \mathrm{g} \mathrm{kg}^{-1}\right)$ of metals in the water sample were $27.3(\mathrm{Cu}), 46.2(\mathrm{Zn}), 0.08(\mathrm{Cd}), 5.1$ $(\mathrm{Ni})$, and $5.8(\mathrm{~Pb})$. The above signifies that $\mathrm{Cu}$ exceeds normally expected levels. $\mathrm{Cu}$ in contaminated soils relates well with the water analysis result. $\mathrm{Fe}$, and $\mathrm{Mn}$ concentrations have not been determined and the $\mathrm{Cd}$ level is not significant. The concentration $\left(\mu \mathrm{g} \mathrm{kg}^{-1}\right)$ of metals in the river water was much less than the industrial effluent: $2.54(\mathrm{Cu}), 35.1(\mathrm{Zn}),<0.05(\mathrm{Cd}),<1.0(\mathrm{Ni})$, and $3.77(\mathrm{~Pb})$ (Fisseha Itanna and Olsson, 2002, unpublished report).

\section{Metal concentrations in treated versus surround- ing untreated soils}

The treated soils at Akaki have elevated $\mathrm{Cu}, \mathrm{Zn}$, $\mathrm{Ni}$, and $\mathrm{Pb}$ concentrations compared to the background soils in the vicinity, as a result of anthropogenic additions (Table 4). Only the surface $\mathrm{Cu}$ value of the treated Vertisol is higher than what is normally a common range for most agricultural soils (0.14-3.18 $\left.\mathrm{mg} \mathrm{kg}^{-1}\right)$, according to Adriano (1986). All of the other horizons fall within this range and contain concentrations above the critical level (i.e., $0.2 \mathrm{mg} \mathrm{kg}^{-1}$ ), provided by Lindsay and Norvell (1978). The Cu concentrations of the background Vertisol and Fluvisol at Akaki also fall within the common range shown above.

$\mathrm{Zn}$ in the treated soils is slightly higher than $\mathrm{Zn}$ in the background soils, but the overall zinc concentration in both treated and background soils is within normal range expected in noncontaminated soils. In the background soils at Akaki, surface $\mathrm{Zn}$ of the Vertisol is about twice as much as the surface $\mathrm{Zn}$ in the Fluvisol.

Fe concentrations in the treated soils are quite high, and their distribution with depth is more or less uniform, with a slightly declining trend. The treated Fluvisol has higher concentrations than that of the treated Vertisol. The background Vertisol and Fluvisol at Akaki also consist of equally high Fe values. Surface Mn of all treated and background soils is very high. It increased consistently with the treated Fluvisol within profile and with the Vertisol it is inconsistent. Similar distribution of $\mathrm{Mn}$ has also been reported elsewhere (Adriano, 1986). There is more enrichment of $\mathrm{Mn}$ in the Fluvisol with depth than the Vertisol.

$\mathrm{Cd}$ concentrations of the treated soils and the background soils are about the same, signifying that no anthropogenic $\mathrm{Cd}$ additions have taken place. On the other hand, there is higher $\mathrm{Ni}$ enrichment in the treated profiles compared to the 
background profiles. Below the surface horizons of both treated soils, $\mathrm{Ni}$ added due to industrial liquid waste is about twice as much as that of the background soils close by. $\mathrm{Pb}$ distribution in the treated Vertisol is about the same with that in the background Vertisol, but distribution within the treated Fluvisol is about twice as much as in the control Fluvisol. In the treated Fluvisol, $\mathrm{Pb}$ decreased consistently with depth opposed to the other metals. A similar decrease of exchangeable $\mathrm{Pb}$ with soil depth in alluvial soils has been reported by Bradley and Cox (1987).

\section{Heavy metal distributions/concentrations in treated soils}

Considering the DTPA micronutrient $(\mathrm{Fe}, \mathrm{Cu}, \mathrm{Zn}$ and $\mathrm{Mn}$ ) concentrations of the two treated soils, the weighted averages of the two soil profiles indicate that the Fluvisol has more DTPA extractable Fe, Mn, and $\mathrm{Zn}$ and lower DTPA $\mathrm{Cu}$ than the Vertisol (Table 2).

$\mathrm{Cd}$ of the surface soil of the treated Vertisol at Akaki is higher than the surface soil Cd content of the Fluvisol (Table 2). It decreases consistently down the horizons in the soil profile of the Vertisol while within the Fluvisol profile it does the same, except that the $\mathrm{Cd}$ level of the Ap horizon is lower than the two underlying horizons. Below the Ap horizons however, there is more enrichment of $\mathrm{Cd}$ in the Fluvisol than the Vertisol.

The Fluvisol contains about double as much lead on the surface and still higher contents throughout the depths of the profiles, than that of the Vertisol. $\mathrm{Pb}$ declines uniformly within depth in both treated soils.

The DTPA metals (plant available forms) constitute a small percentage of the total metal concentrations (Tables 2 and 3). Total metal concentrations in the Fluvisol are generally higher than the Vertisol except for $\mathrm{Cu}$ and $\mathrm{Cd}$.

\section{Influences of soil parameters on metal availabil- ity}

Carbonate and organic matter contents, $\mathrm{pH}$ of the soil, CEC, clay content, etc. are in principle the factors governing the availability and solubility of heavy metals (Basta and Tabatabai, 1992). Accordingly, both soils are carbonate-free, while the Vertisol has higher clay, $\mathrm{CEC}, \mathrm{pH}$ and organic matter contents. Although no fractionation of these metals is made, the $\mathrm{pH}$ values seem to influence the solubility and availability of most metals $(\mathrm{Fe}$, $\mathrm{Mn}, \mathrm{Pb}$, and $\mathrm{Zn}$ ) compared to the other factors (Table 2). Hence, because of the relatively higher $\mathrm{pH}$ content of the soil horizons of the Vertisol, it has relatively lower concentrations of the available metals compared to the Fluvisol. A strong relationship between soil solution $\mathrm{pH}$ and metal adsorption has been demonstrated, with metal adsorption being directly proportional to $\mathrm{pH}$ (Harter 1983; Elliot et al. 1986; Basata and Tabatabai, 1992). Andersen and Christensen (1988) showed that $\mathrm{pH}$ was the most influential factor in determination of distribution coefficients of $\mathrm{Cd}$, $\mathrm{Co}, \mathrm{Ni}$, and $\mathrm{Zn}$ in 38 Danish soils and that other soil properties were less influential.

$\mathrm{Cu}$ content of the surface soil of the Vertisol is above twice that of the surface soil in the Fluvisol because of correspondingly higher organic carbon in the surface soil of the Vertisol. Copper fractionation studies have shown that $\mathrm{Cu}$ existed in soils predominantly as organically bound and residual forms (Zhu and Alva, 1993a). Similar observation is made for surface Ni. Metal adsorption could be described with a combination of these parameters, such as organic matter and $\mathrm{pH}$, etc. (Basta and Tabatabai, 1992).

The Vertisol has much higher CEC than the Fluvisol as presented on Table 1. This certainly also has contributed to reduced heavy metal availability in the Vertisol compared to the Fluvisol. Increased soil $\mathrm{pH}$ due to elevated $\mathrm{Ca}$ and $\mathrm{Mg}$, has a profound effect on the availability and mobility of trace elements (Zhu and Alva, 1993b).

Generally there is enrichment of trace elements in clay and silt fractions (Esser et al., 1991). However, in this particular case the clay rich Vertisol generally has less concentrations of metals than the Fluvisol. This may be due to the greater adsorption of the competing ions like $\mathrm{Ca}$ and $\mathrm{Mg}$ on the clay surface as mentioned above.

Several research results show that generally the concentration of metals decrease with distance from the source and with depth, just like is seen in the Akaki Vertisol (Dowdy and Volk, 1983; Kuo et al., 1983; Pierzynski and Schwab, 1993; Yingming and Corey, 1993). On the other hand, depending on the soil texture, metals can also leach to subsurface horizons and may result on some redistribution of metals within the profile depth, as is the case with the Akaki Fluvisol for most of these metals.

Yingming and Corey (1993) review several reports which indicate that varying degrees of downward movement occur with heavy inputs of sludge-borne trace metals, low soil $\mathrm{pH}$, coarsetextured soils, heavy precipitation or irrigation, or long-term application of sludge. These factors will thus justify the uneven distribution of these metals with the profile of the Fluvisol compared to the Vertisol. 
Table 2. Distribution of some DTPA extractable micronutrients and metals $(\mu \mathrm{g} / \mathrm{g})$ within the treated soils at Akaki.

\begin{tabular}{|c|c|c|c|c|c|c|c|c|}
\hline $\begin{array}{c}\text { Depth } \\
(\mathrm{cm})\end{array}$ & $\begin{array}{c}\text { Soil } \\
\text { horizon }\end{array}$ & $\mathrm{Cu}$ & $\mathrm{Cd}$ & $\mathrm{Fe}$ & $\mathrm{Mn}$ & $\mathrm{Ni}$ & $\mathrm{Pb}$ & $\mathrm{Zn}$ \\
\hline \multicolumn{9}{|c|}{ a. Vertisol } \\
\hline $0-30$ & Ap & 3.93 & 0.019 & 22.8 & 11.7 & 1.55 & 0.57 & 2.35 \\
\hline $30-85$ & B & 2.65 & 0.015 & 18.2 & 5.7 & 0.99 & 0.41 & 1.11 \\
\hline $85-115$ & $\mathrm{BC}$ & 1.66 & 0.010 & 18.2 & 2.9 & 0.71 & 0.23 & 0.45 \\
\hline $115+$ & $\mathrm{C}$ & 1.37 & 0.009 & 17.2 & 5.4 & 0.64 & 0.33 & 0.37 \\
\hline \multicolumn{9}{|c|}{ b. Fluvisol } \\
\hline $0-25$ & Ap & 1.86 & 0.013 & 32.3 & 14.4 & 0.93 & 0.97 & 3.85 \\
\hline $25-80$ & B & 2.84 & 0.018 & 30.7 & 16.9 & 0.93 & 0.73 & 7.87 \\
\hline $80-100$ & $\mathrm{AIIb}$ & 1.73 & 0.016 & 28.1 & 18.6 & 0.96 & 0.50 & 2.47 \\
\hline $100-137$ & $\mathrm{BIIb}$ & 1.60 & 0.013 & 23.0 & 16.9 & 0.96 & 0.42 & 1.11 \\
\hline $137+$ & C & 1.40 & 0.011 & 22.6 & 17.0 & 0.94 & 0.40 & 0.75 \\
\hline
\end{tabular}

Table 3. Total metal concentrations $(\mu \mathrm{g} / \mathrm{g})$ of Akaki treated soils

\begin{tabular}{|c|c|c|c|c|c|c|c|c|}
\hline $\begin{array}{l}\text { Depth } \\
(\mathrm{cm})\end{array}$ & $\begin{array}{c}\begin{array}{c}\text { Soil } \\
\text { horizon }\end{array} \\
\end{array}$ & $\mathrm{Cu}$ & $\mathrm{Cd}$ & $\mathrm{Fe}$ & Mn & $\mathrm{Ni}$ & $\mathrm{Pb}$ & $\mathrm{Zn}$ \\
\hline \multicolumn{9}{|c|}{ a. Vertisol } \\
\hline $0-30$ & Ap & 86 & 1.14 & 121271 & 4106 & 139 & 23 & 1662 \\
\hline $30-85$ & B & 117 & 0.99 & 153272 & 4212 & 137 & 21 & 1662 \\
\hline $85-115$ & $\mathrm{BC}$ & 83 & 0.95 & 124693 & 3936 & 123 & 21 & 1563 \\
\hline $115+$ & $\mathrm{C}$ & 81 & 1.10 & 184724 & 6398 & 227 & 24 & 1619 \\
\hline \multicolumn{9}{|c|}{ b. Fluvisol } \\
\hline $0-25$ & Ap & 64 & 0.97 & 128981 & 4767 & 154 & 49 & 1775 \\
\hline $25-80$ & B & 61 & 0.78 & 189969 & 6447 & 103 & 25 & 1535 \\
\hline $80-100$ & AIIb & 106 & 1.01 & 178249 & 6857 & 169 & 30 & 1745 \\
\hline $100-137$ & BIIb & 74 & 0.72 & 179072 & 7172 & 132 & 30 & 1562 \\
\hline $137+$ & $\mathrm{C}$ & 112 & 0.59 & 185849 & 8005 & 138 & 28 & 1732 \\
\hline
\end{tabular}

Table 4. DTPA extractable metals $(\mu \mathrm{g} / \mathrm{g})$ of the control background soils at Akaki.

\begin{tabular}{|c|c|c|c|c|c|c|c|}
\hline $\begin{array}{c}\text { Depth } \\
(\mathrm{cm})\end{array}$ & $\mathrm{Cu}$ & $\mathrm{Cd}$ & $\mathrm{Fe}$ & $\mathrm{Mn}$ & $\mathrm{Ni}$ & $\mathrm{Pb}$ & $\mathrm{Zn}$ \\
\hline \multicolumn{8}{|c|}{ a. Vertisol } \\
\hline $0-20$ & 2.1 & 0.019 & 25.0 & 13.9 & 1.0 & 0.5 & 1.2 \\
\hline $20-75$ & 2.4 & 0.013 & 24.5 & 6.3 & 0.5 & 0.5 & 0.6 \\
\hline $75-137$ & 2.8 & 0.011 & 20.5 & 4.0 & 0.3 & 0.4 & 0.4 \\
\hline $137+$ & 2.4 & 0.010 & 18.7 & 3.2 & 0.3 & 0.4 & 0.6 \\
\hline \multicolumn{8}{|c|}{ b. Fluvisol } \\
\hline $0-30$ & 1.9 & 0.017 & 24.6 & 10.5 & 1.0 & 0.4 & 0.5 \\
\hline $30-103$ & 1.7 & 0.017 & 24.0 & 7.0 & 0.6 & 0.2 & 0.4 \\
\hline $103-177$ & 1.6 & 0.015 & 24.3 & 6.4 & 0.5 & 0.3 & 0.4 \\
\hline $177+$ & 1.0 & 0.010 & 19.2 & 4.5 & 0.3 & 0.2 & 0.3 \\
\hline
\end{tabular}


Moreover, the coarser texture particle size fractions of the Fluvisol render it with bigger pore spaces and higher potential of water movement. Limited movement through open soil channels or cracks can contribute to longer-range transport (Dowdy and Volk, 1983). In a similar study, Lund et al. (1976) report that enrichments of $\mathrm{Cd}, \mathrm{Cu}$ and $\mathrm{Zn}$ have been observed to a maximum depth of $3.5 \mathrm{~m}$ below sewage disposal ponds.

Another reason for the higher availability of these metals in the Fluvisol is due to the contaminated river sediments, which add up every time. Moore and Luoma (1990) indicate that contaminated sediments are one of the several means through which soils are enriched with heavy metals, especially from mining or industrial sources. Visual observations of the Fluvisol profile also affirm the different layers of sediments deposited in this soil, which contribute to the redistribution of metals within the depth of the soil. Pierzynski and Schwab (1993) reported of elevated $\mathrm{Pb}, \mathrm{Zn}$ and $\mathrm{Cd}$ concentrations in alluvial soils. They assert that contaminated alluvial soils are an important aspect of environmental problems associated with metal accumulation, although not much research has been conducted on such soils, despite the fact that these soils usually are used to grow crops.

\section{Influence of cropping}

Similar crops and agricultural operations take place on both soil types. However, because of the coarse textured-ness of the Fluvisol there will be more downward movement of metals with time as a result of continuous irrigation with metal containing wastes. The relative ease of agricultural operations during ploughing or cultivation could redistribute metals in deeper layers of the Fluvisol compared to the Vertisol. Yingming and Corey (1993) explain that harvest removal, erosion, leaching, and tillage practices (uneven tillage depth) contribute to the redistribution of sludgeborne trace metals applied to field plots. Soil mixing by the soil fauna will have also similar effect.

Farmers at Akaki commonly use DAP to fertilize their vegetables, sometimes together with urea. Application of phosphatic fertilizers have been found to cause P-induced zinc deficiency in soils (Singh et al. 1988; Pierzynski and Schwab, 1993; Fisseha Itanna, 1998b).

\section{Impacts on human health}

The accumulation of heavy metals in soils is a major concern because of the removal of such metals by crops to be grown and the resultant exposure of human and animal life to elevated metals through the food-chain. Moreover, vegetation grown in contaminated sites can have chlorosis, which limits crop production (Pierzynski and Schwab, 1993). Hence, it is important whenever possible to reduce the availability of such metals.

From the plant available metals studied, surface $\mathrm{Cu}$ of the treated Vertisol and $\mathrm{Mn}$ and $\mathrm{Zn}$ contents of the two treated soils are in excess of critical levels. Total metal concentrations also indicate that some $\mathrm{Cu}$ values in both soil profiles and $\mathrm{Fe}, \mathrm{Mn}, \mathrm{Ni}$ and $\mathrm{Zn}$ are in the toxic range. This raises a concern of the possible uptake of this metals by vegetables grown there and later consumed by the urban community. Additionally, the movement of these metals to deeper layers as in the Fluvisol, could lead to contamination of ground water.

\section{CONCLUSIONS AND RECOMMENDATIONS}

Application of wastewater to the farmlands certainly has increased the concentrations of most of the microelements of these soils compared to the background soils studied. The Fluvisol contained about twice as much $\mathrm{Zn}, \mathrm{Pb}, \mathrm{Mn}$ and $\mathrm{Fe}$; considering the overall metal distribution within the depths of the profiles. Overall averages of $\mathrm{Ni}$ and $\mathrm{Cd}$ within the Fluvisol profile also surpassed those in the Vertisol. Organic matter seems to influence surface $\mathrm{Cu}$, and $\mathrm{Ni}$ in the treated Vertisol. Due to the lower soil $\mathrm{pH}$, floodplain soil impacted from river sediments, and relatively coarser soil texture, the Fluvisol is generally more contaminated than the Vertisol.

It can thus be inferred that there is greater risk of metal content in vegetables grown on the Fluvisols compared to those grown on the Vertisols, although land management of Vertisols is more difficult than that of Fluvisols. This needs to be verified in the future through plant analyses of vegetables grown on both soils. Metal concentrations in these soils will certainly continue to rise in the future unless proper measures are taken to reduce discharge of metals into the farmlands. It is thus recommendable that the Akaki Textile Factory makes sure that there is a more efficient treatment of the effluents and less metal discharge of metals into the environment. This information could also be useful for other newly emerging industries at Akaki and elsewhere, to take consideration of waste disposal. 


\section{ACKNOWLEDGEMENTS}

The Ethiopian Science and Technology Commission (ESTC) is acknowledged for its financial support for the field activities during soil sampling. The Department of Soil Science of the University of Saskatchewan in Canada is acknowledged for allowing access to the soil lab and covering lab costs. Thanks are due also to the CIDA-AUCC Ethiopian Project, directed by Dr. A. R. Mermut, for covering partial cost. Mr. Barry Goetz from the Soil Survey Unit of Agriculture Canada has been very helpful during the analysis of the soil samples. The Geology Department of the University of Saskatchewan is acknowledged for the water analyses. The DAAD (German Academic Exchange Service) and the Institute of Soil Science and Site Ecology of the University of Hohenheim are acknowledged for financial assistance and access to facilities, respectively.

\section{REFERENCES}

1. Adriano, D.C. (1986). Trace Elements in the Terrestrial Environment. Springer Verlag, New York.

2. Andersen, P.R. and Christensen, T.H. (1988). Distribution coefficients of $\mathrm{Cd}, \mathrm{Co}, \mathrm{Ni}$ and $\mathrm{Zn}$ in soils. Soil Sci. 39:15-22.

3. Basta, N.T. and Tabatabai, M.A. (1992). Effect of cropping systems on adsorption of metals by soils: II. Effect of pH. Soil Sci. 153(3):195-204.

4. Bidwell, A.M. and Dowdy, R.H. (1987). Cadmium and zinc availability to corn following termination of sewage sludge applications. J. Environ. Qual. 16:438-442.

5. Bradley, S.B. and Cox, J.J. (1987). Heavy metals in the Hamps and Manifold Valleys, North Staffordshire, U.K.: Partitioning of metals in flood plain soils. Sci. Total Environ. 65:135-153.

6. Dowdy, R.J. and Volk, V.V. (1983). Movement of heavy metals in soils. In: Chemical Mobility and Reactivity in Soil Systems, (Nelson, D.W., et al. eds). SSSA, Spec. Publ. 11. Madison, WI.

7 Elliott, H.A., M., R.Liberati, M. and C. Huang, C.P. (1986). Competitive adsorption of heavy metals by soils. J. Environ. Qual. 15:214-219.

8. Esser, K.B., Bockheim, J.G. and Helmke, P.A. (1991). Trace element distribution in soils formed in the Indiana Dunes, USA. Soil Sci. 152(5):340-350.

9. FAO (1988). FAO-UNESCO Soil map of the world, Revised legend. World Soil Rsources Report, 60.

10. Fisseha Itanna (1998a). Comparative study on soil pollution with toxic substances on farmlands close to old and new industrial sites in Ethiopia. Bull. Chem. Soc. Ethiop. 12(2):105-112.

11. Fisseha Itanna (1998b). Metal concentrations of some vegetables irrigated with industrial liquid waste at Akaki, Ethiopia. SINET: Ethiop. J. Sci. 21(1):133144.

12. Fisseha Itanna and Olsson, M. (2002). Land degradation due to industrialization and urbanization in Addis Ababa and its surrounding, central Ethiopia. (unpublished report).

13. Harter, R.D. (1983). Effect of soil $\mathrm{pH}$ on adsorption of lead, copper, zinc, and nickel. Soil Sci. Soc. Am. J. 47:47-51.
14. Korcak, R.F. and Fanning, D.S. (1978). Extractability of cadmium, copper, nickel and zinc by double acid versus DTPA and plant content at excessive soil levels. J. Environ. Qual. 8:361-364.

15. Kuo, S., Heilman, P.E. and Baker, A.S. (1983). Distribution and forms of copper, zinc, cadmium, iron, and manganese in soils near a copper smelter. Soil Sci. 135:101-109.

16. Lindsay, W.L. (1979). Chemical Equilibria in Soils. John Wiley and Sons, New York.

17. Lindsay, W.L. and Norvell, W.A. (1978). Development of a DTPA test for zinc, iron, manganese, and copper. Soil Sci. Soc. Am. J. 42:421-428.

18. Lund, L.J., Page, A.L. and Nelson, C.O. (1976) Movement of metals below sewage disposal ponds. J. Environ. Qual. 5:330-334.

19. Ma, L.Q. and Rao, G.N. (1997). Chemical fractionation of cadmium, copper, nickel, and zinc in contaminated soils. J. Environ. Qual. 26:259-264.

20. McBride, M.B. (1995). Toxic metal accumulation from agricultural use of sludge: are USEPA regulations protective? J. Environ. Qual. 24:5-18.

21. Moore, J.N. and Luoma, S.N. (1990). Hazardous waste from large scale metal extraction. A case study. Environ. Sci. Technol. 24:1278-1285.

22. Pierzynski, G.M. and Schwab, A.P. (1993). Bioavailability of zinc, cadmium, and lead in a metalcontaminated alluvial soil. J. Environ. Qual. 22:247-254.

23. Risser, J.A. and Baker, D.E. (1990). Testing Soils for Toxic Metals. In: Soil Testing and Plant Analysis, (3rd ed.), pp. 275-298, (Westerman, R.L., ed.). SSSA, Inc., Madison, WI.

24. Sheaffer, C.C., Decker, A.M., Chaney, R.L. and Douglas, L.W. (1979). Soil temperature and sewage sludge effects on metals in crop tissue and soils. J. Environ. Qual. 8:455-459

25. Singh, J.P., Karamanos, R.E. and Stewart, J.W.B. (1988). The mechanism of phosphorus-induced zinc deficiency in bean (Phaseolus vulgaris L.). Can. J. Soil Sci. 68:345-358.

26. Sloan, J.J., Dowdy, R.H. and Linden, D.R. (1997). Long-term effects of biosolids applications on heavy metal bioavailability in agricultural soils. J. Environ. Qual. 26:966-974.

27. Valdares, J.M., Gal, M., Mingelgrin, U. and Page, A.L. (1983). Some heavy metals in soils treated with sewage sludge, their effects on yield, and their uptake by plants. J. Environ. Qual. 12:49-57.

28. Venditti, D.S., Durecu, S. and Berthelin, J. (2000). A multidisciplinary approach to assess history, environmental risks, and remediation feasibility of soils contaminated by metallurgical activities. Part A: Chemical and physical properties of metals and leaching ability. Arch. Environ. Contam. Toxicol. 38:411-420.

29. Yingming, L. and Corey, R.B. (1993). Redistribution of sludge-borne cadmium, copper, and zinc in a cultivated plot. J. Environ. Qual. 22:1-8.

30. Zhu, B. and Alva, A.K. (1993a). Distribution of trace metals in some sandy soils under citrus production. Soil Sci. Soc. Am. J. 57:350-355.

31. Zhu, B. and Alva, A.K. (1993b). Differential adsorption of trace metals by soils as influenced exchangeable cations and ionic strength. Soil Sci. 155(1): 61-66. 